\title{
ARTICLE
}

\section{Colonised's Madness, Colonisers' Modernity and International Law: Mythological Materialism in the East-West Telos}

\section{Prabhakar Singh*}

\begin{abstract}
This monograph takes on "modern art" as the location of modernity. This subject, in my view, holds potential for a productive multi-logue and not just a dialogue, between three binary socio-cultural categories: child and adult, normal and mad, and colonisers and colonised. Modern art raises very interesting questions, and as an area that is often ignored in the analysis of law and science, it forms a powerful field for exploring both, as well as their intersections. Exploring the psychology of colonisation/domination is an important objective of this monograph. In order to get at it, the monograph imbibes Appadurai, Foucault, and Nandy as offering complementary stances on modernity and subsequent globalisation of intraEuropean relations after the industrial revolution. In doing so the author relates aspects of semiotic theory by looking at theories of myth. This monograph concludes by applying their relevance to the strategy of signification deployed by international law and relations.
\end{abstract}

\section{Keywords}

Ancient, Art, Beauty, Childhood, Colonisation, Racism, Mythological Materialism, Phenomenology, Modernity, Semiotics, International Law

* Assistant Professor, Jindal Global Law School. B.A./LL.B(National Law Institute University, Bhopal), LL.M.(Barcelona). I am thankful to the reviewer of the Journal, an expert on German Philosophy for substantive blind review, shilpi Bhattacharya for making corrections, and Raeesa Vakil for her research assistance. The views expressed in this monograph, however, can only be attributed to me alone. The author can be contacted at: prabhakarsingh.adv@gmail.com/Address: Room No: A-226, O.P.Jindal Global University, Jagdishpur Village, NCR of Delhi, 131001, INDIA. 


\section{Introduction}

"Der Zeit ihre Kunst, der Kunst ihre Freiheit"

Ludwig Hevesi, Vienna Secession of 1897

This German maxim translates as: to our era its art, to art its freedom. There is nothing new about the discourse on art, myth and modernity. But it is exciting nonetheless. Such has been the pervasiveness of modernity that new facets emerge every time an author takes on modernity. Today a discourse of modernity must not remain an exclusive preserve of anthropologists and sociologists; it should now engage as many international lawyers as possible. A series of thinkers first from the West and then from the East have spoken about modernity and capitalism. Michel Foucault, 1 Arjun Appadurai, ${ }^{2}$ and Ashis Nandy, ${ }^{3}$ among many others, are some of the names that I personally find stimulating and revealing. They have spoken about modernity and colonisation, and its effects in shaping our consciousness about how modernity has altered societal relations producing conflicts within and outside colonised societies the contents of postcolonial studies. In more layman's term, modernity evokes hesitation, often timorous, as human conscience around the world has shown a fetish for its past.

Appadurai's decisive discourse on modernity reveals modernity's ability to create five kinds of pasts. These are history, tradition, evolution, antiquity and civilisation. 4 "India," Ashis Nandy analyses, "has many pasts; depending upon the needs of each age, the nation brings a particular past into its consciousness." 5 I am of the view that such choices of pasts are guided by two aspects of human psychology. They are:

1. A particular culture's obsession for particular mythology as the 'real' history, and

1 It would be unfair to cite a single work of Foucault for the purposes of this monograph. All his works, i.e. Madness and Civilization, The Birth of the Clinic, The Order of Things, Discipline and Punish, and three volumes of The History of Sexuality can all be read chronologically to get at his deductions. They have thus been cited as and when needed throughout the monograph. Between "The Archeology of Knowledge" and "Discipline and Punish" Foucault did change-a reading of Nietzsche's "Genealogy of Morals" shifted his model of history - from a layered view to directionless branches. This turned out to be boon for new studies that followed, and it is also true about this current monograph.

2 ArJun Appadurai, Modernity at Large: Cultural Dimensions of Globalization (1996).

3 Ashis Nandy, The Intimate Enemy: Loss of Recovery of Self Under Colonialism, in ExILED AT Home V (Ashis NANDY ED., 2002).

4 Steney Shami, Prehistories of Globalisation: Circassian Identity in motion, Globalisation, 220-21(ARJUn APPADURAI ED., 2001).

5 Nandy, supra note 3, at 47-48. 
2. Cultures' abhorrence of science and technology that often create conflicting social situations, new modes of interaction, and new behavioural changes rekindling the "old-new" or "modern-ancient" debate.

The political and cultural sphere of India has witnessed a fierce battle between forces that are folk and Sanskritic. The Constitution of India and the political turmoil of the 80s and the 90s amply reflect this. ${ }^{6}$ In its lived experience, the humanity has shown marked love for one or the other kind of past at different times. Therefore, the coloniser and the colonised held to different choices: of the types of past offered in Appadurai's analysis, coloniser chose civilisation, history and evolution whereas the colonised settled with tradition and antiquity as their authentic past. The psychological pull behind choosing a type of past lies in its ability to distract people, Eastern or Western, and offering relaxing co-ordinates which direct their imagination to glory, prosperity, happiness, wealth and good environment. Nonetheless, Appadurai identifies a minimal set of four formal constraints on all sets of norms about past. These are authority, continuity, depth and interdependence arguably present in all kinds of cultures.7 Says Nandy, colonisers saw history as reality as against myth:

\begin{abstract}
...being a flawed, irrational fairy tale produced by 'unconscious' history, meant for savage and children. The core of such a concept of time- produced in the West for the first time after the demise of medievalism - consists in the emphasis on causes rather than on structures, on progress and evolution as opposed to self-realization-in-being, and on the rationality of adjustment to historical reality ... 8
\end{abstract}

Thus a set of impromptu questions follow from this discussion: what is the relation of myth/mythology, antiquity, history and tradition with modern art and to the lived experience of humans? Can we use art and myth to see history and perceive reality in the way Marx perceived his, using historical materialism? Can we not see reality through the prism of what I call "mythological materialism?" Can modern art and myth become the explanatory coordinates of reality? In other words, can reality be the myth that colours art? Or is it the myth that colours realty using art?

Such questions beg sustained discussions on modern art as the location of modernity. Post-modernists and anti-modernists have indulged in such enquiries before. Such an exercise has been primarily a task in the epistemology of myth,

6 A.G. Noorani, The Constitution and the course of politics, 17:7 FrontuIne, Apr. 1, 2000, available at http://www.hinduonnet.com/fline/fl1707/17070820.htm (last visited on Feb. 8, 2010). For detaills, see GrANVILLE Austin, Working a Democratic Constitution: The Indian Experience (2000).

7 Arjun Appadurai, The Past as a Scarce Resource, 16 MAN 203, 201-219 (1981).

8 Nandy, supra note 3 , at 60 . 
imaginations, capitalism, consciousness, and narratives of modernity. A sustained discussion on art as the location of modernity also informs the coloniser-colonised relation for now it is widely evident that the East and West have different purposive intent behind their pastoral choice. The coloniser-colonised debate, by its nature, leads us to issues of racism, imagination of men as sub-human, native science as folk, knowledge as ignorance and modernity of the 'Other' being Western myth. Postcolonial theories, thus, remain ...

[w]edded to ways of conceiving the relation of the non West to the West, and of conceiving human motivation and political agency more generally, that emerged from a distinctively European mid twentieth-century intellectual climate in which non-Western peoples and societies were understood to be in principle incapable of historical emancipatory agency until "jump-started" by Western material and conceptual colonial violence. 9

Throughout this monograph, the term 'myth' has been used in a number of its guises: the Barthean-identified framework of understanding where systems of knowledge are understood as 'truth' within a cultural context; in its form as the label used in European discourses de-legitimising other knowledge as lacking in scientific ground; and as allegorical stories of folk and tribal cultures. This has been done to encapsulate myth in a comprehensive fashion. As the story of myth traverses different sections of the monograph, it will become evident which of the above meanings of myth has been applied. This composite nature of myth has a mutually exchangeable set of actors - as symbols that appear different on its face but emerge from similar psyche.

A European child and a colonised native thus will appear as two inseparable sides of a single coin. Modern art will appear as violent and destructive as the forces of science. Colonisers will seemingly acquire a paedophile's face and an artist will become a ruthless cog in the dialectic of historical materialism. In such a narration, international law becomes an unpopular and vicious project that endorses historical materialism as against more nuanced mythological materialism.10 The table below has been prepared with an aim to throw a comparative light on 'mythological' materialism.

9 Donald Wehrs, Sartre's Legacy in Postcolonial Theory; Or, Who's Afraid of Non-Western Historiography and Cultural Studies? 34 NEW LiteraRY Hist. 763, 761-89 (2003).

10 I have discussed the role of myth, native knowledge and international law's construction in, Prabhakar Singh, The Scandal of Enlightenment and the Birth of Discipline: Is International Law a Science? 12(1) INT' L. Commum' Y. L. REv. 5-34 (2010). 
Table 1: Distinctions between Historical and Mythological Materialism

\begin{tabular}{|l|l|}
\hline $\begin{array}{l}\text { Historical Materialism } \\
\text { (Marx/Mainstream ) }\end{array}$ & $\begin{array}{l}\text { Mythological Materialism } \\
\text { (Current author/alternative) }\end{array}$ \\
\hline $\begin{array}{l}\text { Colonisers' chief tool of exploitation } \\
\text { Starts by defining history }\end{array}$ & $\begin{array}{l}\text { Colonised's only way of resurrection } \\
\text { Pits mythology as true' alternative to history }\end{array}$ \\
\hline History as the story of class struggle & Mythology is the true history \\
\hline Thesis, anti-thesis and synthesis & No contradiction/antagonism \\
\hline Deterministic and scientific & $\begin{array}{l}\text { Accommodates ideas, imaginations and role } \\
\text { of psyche (allegedly non-scientific) }\end{array}$ \\
\hline $\begin{array}{l}\text { Inspired by Hegel and Kant and propounded } \\
\text { by Karl Marx }\end{array}$ & $\begin{array}{l}\text { Nietzsche, Foucault, Sartre, Said, Nandy can } \\
\text { be said to be its proponents }\end{array}$ \\
\hline Conflict as the basis of historical development & $\begin{array}{l}\text { Cohabitation and peaceful existence as the } \\
\text { engine of growth }\end{array}$ \\
\hline Progress as linear & Progress is circular \\
\hline Ignores the role of emotions & Emotive aspects equally important \\
\hline $\begin{array}{l}\text { History here is sponsored and written } \\
\text { (kings, chiefs and colonisers) }\end{array}$ & $\begin{array}{l}\text { Ahistoricals, historyless and subalterners are } \\
\text { the major agents of mythology (e.g. women, } \\
\text { peasants and children) }\end{array}$ \\
\hline Enlightenment as the source of knowledge & Treats Enlightenment as an scandal \\
\hline Non-interdisciplinary & Multidisciplinary vision \\
\hline War, destruction and fresh beginning & Continuity, eternity and seamless progress \\
\hline Preserved as written text & Found in folklore and oral traditions \\
\hline
\end{tabular}

Source: Edited by the author

An attempt at defining mythological materialism's phenomenology is an exercise in semiotics of both sociology and anthropology; international law has understandably avoided myth for history. Mythological materialism signifies the struggle between various narratives of competing pasts which eventually characterise particular cultures' symbiotic semiotics. Mythology essentially is a kind of symbolism, thus semiotic in its appeal to cultural relativism and its detractors both. I am often tempted to see Gandhi as the chief protagonist of mythological materialism. This will be discussed later via narrative of Gandhi by Nandy, though very briefly. Thus, following pages will engage the readers in a discussion about myth, history, art and modernity. Modern art will be used to explain an industrialised modern view that was instrumental in the superiority claims made by the colonisers. 


\section{Examples of Myth as History and History as Myth: The Case of Greek Alexander and Nazi Hitler}

Our dreams and imaginations both, says Foucault, are seemingly made of the same matter.11 Both offer soothing solutions to consciousness, albeit, mostly intangible. Yet consciousness has never been argued as constituting one of the types of past, partly because the discussion of history is not aimed at creating solutions. History as an offering to the non-dominant, the subaltern, the uncivilised, the heathen, the folk and the non-modern has been made possible by "ideology" of the Western intellectuals. 12 Ideology uses history as a device of political explanation of world events. It sees history as a monolithic and homogeneous process - it does not offer "history of the world" as it is, but "world-as-history." 13 Therefore, an ambitious and war-mongering Greek Alexander was written by Western historians as "Alexander the great" and not a villain of history. On the contrary many war-mongers from the East with similar ambitions were simply invaders who invaded the West. History is thus simply an agenda of the dominant ideologue of a particular time. The untold sufferings inflicted upon India by Alexander;

[m]assacre, rapine, and plunder on a scale till then without a precedent in her annals, but [was] repeated in later days by more successful [Muslim] invaders like Sultan Mahmud, Tamerlane, and Nadir Shah. In spite of the halo of romance that Greek writers have woven round the name of Alexander, the historians of India can regard him only as the precursor of these recognized scourges of Mankind. This may be an extreme statement. But so is the statement that Alexander proclaimed for the first time the unity and brotherhood of mankind. 14

Alexander's campaign in India was therefore certainly not a political success. It is also true that it left no permanent mark on the literature, life, or government of the people. 15 The name of Alexander is not found in Indian literature; the folk or the the folk or the unwritten and the oral history. How can the oral traditions bypass an invasion of such magnitude as Alexander's? Oral folk traditions, which at most paints and pictures their narratives, cannot lie, as they are not-state sponsored for creating an official version of

11 Michel Foucault, Madness and Civilization: A History of Insanity in the Age of Reason, 96-100(Richard Howard trans., 2003).

12 See Antonio Gramsci, Intellectuals, in Selections from the Prison Notebooks of A. Gramsci 5-23 (2010).

13 Philippe Lacoue-Labarthe \& Jean-Luc Nancy (Brian Holmes trans.), The Nazi Myth, 16 CRITICAL InQUIRY 293, $291-312$ (1990).

14 A. K. Narain, Alexander and India, 12 GREECE \& RoME, 162, 155-165 (1965).

15 Id. 
history. Certainly, Alexander did not intend his conquests in India to be as meaningless as this. But it was so.16 What we see today as history is a substantial signification of rather insignificant truths. Alexander's greatness and his conquests in India are but myths have been written as history. It was this assigned valour that the Nazis tried to emulate along with the Greek tradition of art, discussed later in greater details. No wonder, Hitler died as frustrated as Alexander as both had their life shortened; Alexander's by a poisonous arrow through his chest and Hitler's by a bullet through his head. And yet, Alexander is a hero and Hitler a villain of history. Why? Probably because Alexander waged a war on non-Greeks, non-Whites, the Semites and coloured Asians whereas Hitler tortured the French, the Polish and other ethnic communities victimising the Jews; who were whites, nonetheless.

\section{Semiotics of the Modern Art as Violent: Art, Myth and Colonisation}

During the early $14^{\text {th }}$ and $15^{\text {th }}$ century when colonisation was more a fashion, a form of artistic expression than a planned activity, the 'ideology' of the French, the English, the Dutch and the like was to see themselves helping in the development of the rest of the world. The Germans were late risers. In a world of nearly patented ideology of "colonisation," the Germans encountered a destabilising inferiority complex, particularly because Germans as nations had no distinctive ideology for their own. The lack of a "Grand Art" was part of this inferiority complex for a nation that saw itself as a pure 'Aryan' race in the world. In a work published in 1869, J.W. Jackson tells us how Aryans are different from Semite: "influenced by his predominant moral principles, the Semite believes and worships, where the Aryan, guided by his preponderating intellectual faculties, investigates facts and deduces conclusion." 17 The Germans took to imitation of myth as an exercise in acquiring art. Translations of Europe's overall disenchantments, together with a particular section of European population that subsequently is identified as the father of the middle class, with its own life into theories of natural and social science, has been possible by the birth of various disciplines, including avant garde modern art.

The absence of art in a political culture can be suicidal if seen semantically. We have seen that insecurity about the absence of a "grand art" in the German consciousness

16 Id.

17 J.W. Jackson, The Aryan and the Semite, 7:27 ANTHRopologicAl REv. 335, 333-65 (1869). 
forced them to embrace Nazism; psychologically Nazism can actually be interpreted as a movement of racial purification through symbolism of swastika, exhibiting high degree of psychosocial manifestation of politico-cultural semiotics.

\section{A. Violent modern Art and Childhood}

In his book - "Philosophy of History" - Hegel recalls comparing the Greek world with a period of adolescence, and how individuality was aesthetically conditioned.18 And yet this was not for the first time that a section of European consciousness had shown how violent absence of art could become while discarding mythology. The Greek political thoughts, later idealised in Germanic imaginations, showed a fear of mythology when philosophers like Plato and the like, called for banishing myth for a modern political history. Plato had embraced historical materialism without speaking about it and Gandhi rejected it in practice. I will engage in a "Plato-Gandhi" discourse again in other sections. Nonetheless, I need not emphasize the limitation that I ought to respect in this monograph. If at all Hitler was motivated by any non-Germanic ideals; it was by the [mis] givings of the Greeks. 19

What it eventually produced was ugly and despicable, that too in a bid to acquire an authentic art! Thus, not only can the struggle for art turn ugly, bloody and cruel but it can induce cultures and societies into violence and brutality. It can poison the vision of an entire community like the Nazis who angered by the absence of left-over territory for colonisation, took to the idea of punishing European nations for gobbling up their imagined share in colonial booty. Colonisation, as an avenue for development as Marx had expressly prescribed, from now on should be seen as natural fallout of an artistic regression of modern Europe. Some scholars have, to an extent, rightly grasped this psychological waning of Nazi Germany in its search for a "grand art." 20

What Germany lacked, therefore, in practical terms, was its subject Consequently, what Germany wanted to create was such a subject, its own subject. This explains its intellectual and aesthetic voluntarism ... as a "will to art." If the Germans' obsession or fear was always that of failing to become artists, of not being able to accede to "great Art"; if in their art or their practice there was often such an effort, and so many theoretical expectations, it is because what was at stake was their identity (or the vertigo of an absence of identity). ${ }^{21}$

\footnotetext{
18 F. Hegel, Philosophy of History, in 43 Great Books of the Western World: A Chronology of Great Authors, 274282 (MoRTimer ADLER ED., 2007).

19 Lacoue-Labarthe \& Nancy, supra note 13, at 299.

20 Lacoue-Labarthe \& Nancy, supra note 13, at 299.

21 Id. at 299.
} 
Art is often seen as beautiful, child-like, non- violent, poetic, aesthetic, meek, and passive. This, as discussed above, is not true at all. A non-Western alternative vision of modern art, thus, sees art as a major culprit of violence against the non-West. The colonial scheme of the Europeans is an anti-thesis of the attributed innocence to art. I, therefore, wonder whether is it art which has caused colonisation on a psychological level? This psychological change did not go unnoticed in European societies. Charity begins at home and so-before Europe went on a colonising spree-they colonised the European childhood only to see its alter ego in natives later. There is no better example of a racist text than the scholarship of Jackson who claims no "utterance of prejudice, but the simple statement of fact." 22 This is one of the most unscientific and narcissistic of literatures that we might come across in any academic journal.23 He testifies thus:

In the Negroid type, the brain lacks volume; the nervous system is not adequately centralised: and this brain, thus deficient in quantity, is equally wanting in quality24 ... the Aryan of the Europe is, and - to the remotest verge of history - always has been, the perfection of his type, whether we regard strength, stature, beauty, or longetivity. 25

After dismantling the Negroid races on the basis of their appearance, he brings down the Indian-Aryans for its primitivism. The truth indeed is - he continues -that the Aryan patriarchs, who celebrated their simple sacrifices to the sacred chants of the Vedic hymns, were isolated strangers maintaining themselves only by the utmost efforts against the incessant attacks of the alien races.26 [Emphasis added] What if such a perception about the colonised native influenced how the colonisers saw their own child colonisation corrupted the colonisers as much as it harmed the colonised. The colonisers treated people of the Negroid race, children and colonised as one and the same, and thus gave same treatment. International law, as an instrument of its own proliferation, cannot be assumed to be free of such sentiments. Colonialism dutifully picked up these ideas of growth and development and drew parallels, as discussed next, between primitivism and childhood.

\section{B. Childhood in Wake of Industrialisation and Colonisation}

Nandy, on the strength of his research, argues that the modern concept of childhood is a

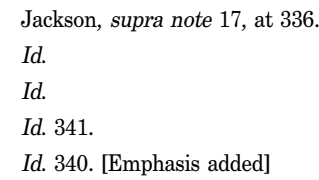


product of seventeenth century Europe. ${ }^{27}$ Foucault had already said earlier that 'man' was an invention of the eighteenth century.28 There is then no option, but to conclude that both manhood and childhood are a recent inventions. Regnant in Europe, the new concept of childhood bears a direct relationship to the doctrine of progress. ${ }^{29}$ Says Nandy:

Child was not seen as beginner of life but as someone opposed to an adult, for example - an inferior version of maturity, less productive and ethical, and badly contaminated by the playful, irresponsible and spontaneous aspects of human nature ... it became the responsibility of the adult to 'save' the child from a state of unrepentant, reprobate sinfulness through proper socialisation, and help child grow towards a Calvinist ideal of adulthood and maturity. 30

This paradigm shift in the perception of childhood alone pushed the innocence of European childhood into factories. The exploitation of children in Britain during the early phase of factories. The exploitation industrial revolution was a natural corollary of such fabrication of fictional childhood. It was planned and orchestrated by capitalist modernity. It was a new justification for child labour; a child as a vile adult in disguise who had to be reformed so that $\mathrm{s} /$ he becomes a civilised adult when a grown-up. Factories, as new avenues for child-labour, were a new schools that corrupt and selfish modernity had gifted to childhood. Factories were new houses of correction for the children who, for the capitalist, formed a soft fleet of workers demanding meagre wages and supplying undemanding labour. They came as a bonus with working women who, in the changed industrialised society, had to divide their motherhood between factory hours and home time.

Thus, childhood - as an important aspect of a women's motherhood - drastically transformed modern art in the industrial sociology of modernising Europe. This is what I intend to convey when I say that the new art saw the child as under-grown adult though I am not the first to speak about it. It is widely known that famous men of creativity, artists and sculptures of modern times had indulged in paedophilic activities. ${ }^{31}$ Molestation of childhood; mental, emotional, psychological, sexual and

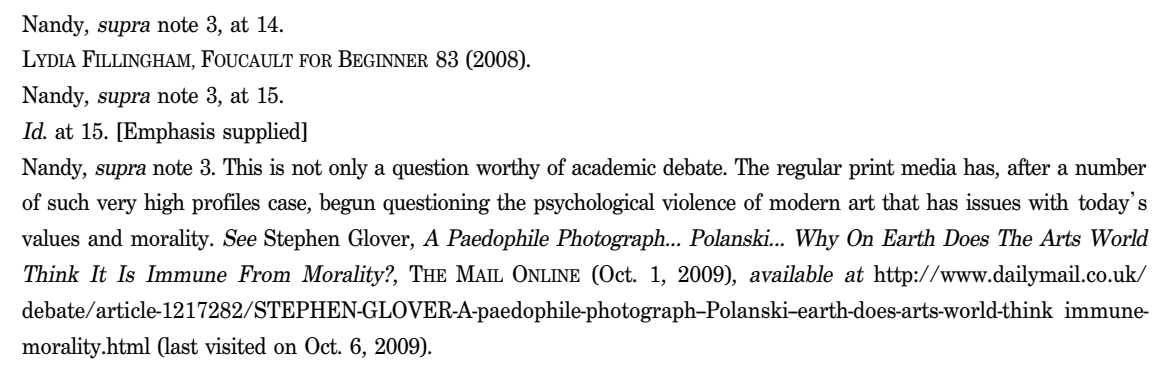


industrial, was another violence that art had inflicted on the society encouraged by lusty modernisation. Later, the colonisers saw same opportunity of molestation when they came across the coloured and so called heathen natives of the non-West. Like childhood, the natives presented them an opportunity of exploitation of so a high market value.

Table 2 : Parallels between primitivism of colonised and the conception of childhood by the colonisers

\begin{tabular}{|l|l|}
\hline Colonisation & Childhood \\
\hline Colonisers & Artists, Industrialists \\
\hline Natives (ugly, uncivilized, primitive) & $\begin{array}{l}\text { Children(foolish, needing discipline, } \\
\text { childish/childlike) }\end{array}$ \\
\hline Funded by Capitalists for trade & $\begin{array}{l}\text { Exploited through art, expression and } \\
\text { paedophilic activities }\end{array}$ \\
\hline Masculine, adult & $\begin{array}{l}\text { Feminine, vile-adult/inferior adult needing } \\
\text { correction }\end{array}$ \\
\hline Calvinistic ideal of maturity & No more a "blissful prototype of beatific angels" \\
\hline $\begin{array}{l}\text { Ahisorical, culturless sub-humans needing } \\
\text { enlightenment }\end{array}$ & $\begin{array}{l}\text { Blank slate on which adult must write moral } \\
\text { code }\end{array}$ \\
\hline $\begin{array}{l}\text { Duty of colonizers to "save" children from } \\
\text { a state of unrepentant, reprobate sinfulness } \\
\text { through imparting civilization } \\
\text { Source: By the author }\end{array}$ & $\begin{array}{l}\text { Rural, sinful, and spare the rod and spoil the } \\
\text { child }\end{array}$ \\
\hline
\end{tabular}

Source: Edited by the author (based on the text by Nandy, supra note 3, at 14-15)

The colonised, like the European children, could be turned into almost rightless labourers who would aid the colonisers in exploiting their very own natural resources at the same time mutilating their culture by the psychological forces that colonial encounters released. Colonisers' psyche of spreading modernity, thus, saw the nonEuropean natives in a way similar to European children; as a soft bunch of underdeveloped humanity waiting to be corrected by industrialisation and Calvanisation. The elitist historiography was always a useful tool to control artistic expressions by private sponsorship subverting any objections to behavioural changes under capitalist aesthetics. This new capitalist aesthetics gave shade to modern art as well. Because of the salient priorities of capitalism; seed-money, cheap labour, racial division, and colonial influences, art was prioritised by new subjects, images, moralism and ideals. Modern art is often associated with invoking realism and restoring prudence, but at the cost of beauty. Art, indeed, brought existing sociology and changing location of anthropology on hessian. But what is often ignored is that this new painting on canvas 
was not automatic; it was sponsored by capitalists legitimising modernity's priorities. The industrial sociology of womanhood, motherhood and childhood in seventeenth century Europe was a crystal ball of a future yet to unfold.

\section{Politics, Art and Modernity: The Vision of Mythological Materialism}

\section{A. Kant and Beauty}

In "Critique of Aesthetic Judgement," Kant defines concepts like taste, beauty, aesthetics, types of delight, and judgement. 32 For him, the antonym for 'aesthetic' is 'logical.' 33 The beautiful is, Kant says, that which, apart from concept, pleases universally. 34 One of the most important tasks for a transcendental philosopher, he continues, and I presume he counts himself as one of them, is to ascertain the universality of aesthetics. 35

A judgement of taste by which an object is described as beautiful, under the condition of a definite concept, is not pure. There are two kinds of beauty: free beauty (pulchritude vaga), or beauty which is merely dependent (pulchritude adhaerens). The first presupposes no concepts of what the object should be; the second does presuppose such a concept, with it, an answering perfection of the object ... Beauty of man (including under this head that of a man, woman, or child), the beauty of ..., and is therefore merely appendant beauty. 36

By deduction, the men of other cultures other than his own are a subject of Kantian enquiry under pulchritude adhaerenes, i.e. a breed constantly looking for example to copy from. For Kant to believe that a work is a work of art indeed "some work of man is always" necessary. 37 A later variant of racial and cultural superiority known as National Socialism should, therefore, not come as surprise: if it did not lead to "aestheticisation of politics" or "politicisation of art," but rather a fusion of politics and art, the production of "the political" as a work of art. 38 As early as Hegel, the Greek world saw cities as

Kant, Critique of Aesthetic Judgment, in 39 Great Books of the Western World: A Chronology of the Great Authors, 476-77 (MORTIMER ADLER ED., 2007).

33 Id. at 481.

34 Id. at 483.

35 Id. at 480.

36 Id. at 488.

37 Id. at 523.

38 Lacoue-Labarthe \& Nancy, supra note 13, at 303. 
work of art. 39 Plato apprehended a dangerous liaison between myth and art. He feared myth so much so that he argued for purging it out of the history of the Greeks. Myth, as he saw had the function of exemplarity and ability to fashion "plastic art." 40 But for Levi-Strauss "what gives the myth an operative value is that the specific pattern described is everlasting." 41 However, unlike sciences, natural and social, art could not be directly harnessed, industrially, for bolstering imperialism.

The semiotic understanding of modern art as violence-boosting is collateral and psychological. The construction of the modern myth or the modern work of art, therefore, is the result of a dialectical process. "And that is exactly why what we called the 'aesthetic solution' is inseparable from the philosophical and theoretical solution." 42 Often the non-West is accused of eulogising its mythological superiority. Arguably, Levi-Strauss defends this by his observation that for cultures and societies "repetition has as his function to make the superstructure of the myth apparent." 43

Modernity has obscured myth for a history that was non-repetitive. It is modern art, modernity's one of the visages of modernity, that bespectacled modernity to see men as ancient and modern, folk and classic, scientific and unscientific, methodical and wayward, calculative and naïve, cultured and barbaric, historical and mythological, prudent and imaginative and provider and needy. The modern art as against the fine art is a product of a paradigm shift in the world view on aesthetics and usefulness. Picasso's famous cubism, therefore, viewing the world from a rectangular window is no wonder, is one of the most celebrated idea of modern art. Modernity has thus replaced symmetry; an idea based on aesthetics, by geometry; an accurate science that uses mathematics.

\section{B. Tragedy, Art and War: From Plato to Nietzsche}

On January 17, 1946 before the Nurembourg Trial it was argued that "if it is proved that a superior race is to annihilate races and peoples that are considered inferior and decadent, incapable of living a life as it should be lived, before what means of extermination will they recoil?" 44 This is the ethics of immorality, the result of the most authentic Nietzscheism, which considers that the destruction of all conventional ethics is the supreme duty of man.

\footnotetext{
Id. at 303 .

40 Id. at 297.

41 Claude Levi-Strauss, The Structural Study of Myth, 68 J. AM. FolKLoRE 430, 428-444(1955).

42 Lacoue-Labarthe \& Nancy, supra note 13, at 309.

43 Levi-Strauss, supra note 41 , at 443.

44 Nuremberg Trial Proceedings, Vol. 5, Thirty-Sixth Day, Thursday, 17 January 1946, Morning Session, 422, available at http://avalon.law.yale.edu/imt/01-17-46.asp (last visited Mar. 10, 2010).
} 
Nietzsche's "The Birth of Tragedy" establishes a parallel between
(a) the victory of the Greeks over the Persians and,
(b) the victory of the Germans over the French.

In other words it draws a parallel between,

(c) the cult of Dionysus in Greece, and

(d) the revolutionary sweep in Europe.

Thus by the same analogy, as were the fifth century Greeks forced to make a difficult choice and they found Aeschylus so did Europe-says Nietzsche- find Wagner; the genius of music-drama. Through the Appolline drama, what happened on stage gave pleasure to the audience, because the heroes take on its suffering. Suffering then becomes enjoyment. Wagner, famous drama-musician in 1871 enjoyed the reputation of being a revolutionary one. 45 Nietzsche was later cited in the Nurembourg Trial on January 17, 1946 of war criminals - a price that he paid posthumously of such involuntary Nazi glory. 46

The colossal of modernity stands on these geometrical pillars mapped by disenchanted capitalists - the famous conclusion of post-modernism. 47 The early capitalist were both producers and consumers of modernity. It only made sense for them to exploit modernity's economies of scale. What lay before them was an idea which if translated into action would redeem Europe, politically, economically and historically.

45 Marc SaUteT, Nietzsche For Beginners 52-58 (2010).

46 Nietzsche was cited thus: "Over a people in this state of spiritual crisis and of negations of traditional values the culminating philosophy of Nietzsche was to exercise a dominant influence. In taking the will to power as a point of departure, Nietzsche preached, certainly not inhumanity but superhumanity. If there is no final cause in the universe, man, whose body is matter which is at once feeling and thinking, may mould the world to his desire, choosing as his guide a militant biology. If the supreme end of humanity is a feeling of victorious fullness which is both material and spiritual, all that remains is to insure the selection of physical specimens, who become the new aristocracy of masters. For Nietzsche the industrial evolution necessarily entails the rule of the masses, the automatism and the shaping of the working multitudes. The state endures only by virtue of an elite of vigorous personalities who, by the methods so admirably defined by Machiavelli, which alone are in accord with the laws of life, will lead men by force and by ruse simultaneously, for men are and remain wicked and perverse. Without doubt, the late philosophy of Nietzsche cannot be identified with the brutal simplicity of National Socialism. Nevertheless, National Socialism was wont to glorify Nietzsche as one of its ancestors. And justly so, for he was the first to formulate in a coherent manner criticism of the traditional values of humanism; and also, because his conception of the government of the masses by masters knowing no restraint is a preview of the Nazi regime. Besides, Nietzsche believed in the sovereign race and attributed primacy to Germany, whom he considered endowed with a youthful soul and unquenchable resources. See Nuremberg Trial Proceedings, supra note 44, at 375, 376.

47 Jim Powell, Postmodernism For Beginners (2010). 
Europe that was now in the grips of unemployment, wars and poverty candidly accepted logics of scale economies. But this logic had its side effect which even its detractors did not want to point out. Therefore, for an anti-modern Nietzsche, the total character of the world is in all eternity a chaos. His world is defined by a lack of order, arrangement, form, beauty, wisdom, and whatever other names there are for our aesthetic anthropomorphisms. Such arguments did not help in the least those who were to become debtors of modernity. The non-West had to buy modernity from its sellers whose merchandise had high discursive aftermaths. The recipe of modernity was sold as a cure to obscurantism, ignorance and the lack of secular hierarchies in India, for example. Instantly, it befriended the aristocracy of the new land; a breed of third world aristocracy that sought to align its history with the feudal history of Europe, an act of identification with the aggressor, as Nandy puts it. 48 It immediately traded myth for history.

In return, the impotent aristocracy, princely states and decaying monarchy of the colonised world received a fresh lease of life at the cost of the subaltern, the tribal and the folk. Post modernists' anti-science links the aesthetics of the East to the disenchantment of the West with modernity. However, the Eastern epistemology never produced knowledge that saw the cosmos scheme-less. Mythology, at its cognitive best, links mass emotion to concepts: concepts that are revolutionary, non-revolutionary or none of these. In oriental cultures, scientific discourses and inventions are often the preserve of 'tradition' mostly oral.

Because of this, what it mostly contains is the end result; detailed formulation of any invention cannot possibly be transferred to semiotics. Thus science, as a thankless imitation, can also be defined as a process of materialising the semiotics of mythology. In fact this is what science has done. Concepts of progress (like spreading civilisation, burden of enlightening, conquering the entire world and modernising the non-modern) and Nazism were both seen as scientific: an effort of imitation by both -- Nazism and the Science -- exposes them. But, unlike Nietzsche's frustration, the East witnessed a political decline before intellectual disenchantment and, therefore, the East is marked by an absence of a chaos theories.

\footnotetext{
48 Ashis Nandy, The Psychology of Colonialism, in Nandy, supra note 3, at 7. This is not to say that Gandhi did not have detractors. Naicker's dissent was not with Gandhi but with his own identity as a Tamil Hindu. Even though he bored name of Rama the most successful of all Hindu Gods, often highly politicised, Naicker claimed a non-Hindu Tamil identity. The Sri Lankan "Singhal-Tamil" disputes are an offshoot of similar identity crisis. But what is important about Gandhi is that he was the first visionary national politician who appreciated the plight of the non-elites and demanded their emancipation. How can one forget the seminal work of Gandhi in social and political upliftment of the untouchables, calling them the men of God (Harijan) and empowerment of women though cooperative self-sufficient village economy. Thus what he preached in India came from his South African experience with apartheid. See P. C. Aggarwal, Halfway to Equality: The HaRiJans of India (1983).
} 


\section{Myth, Colonisation and Gandhi: Ideological Transplant}

The intellectual borrowings of international law, if any, from modern art his disregarded the aboriginal and village world view as non-modern and heathen. The Greeks were the Aryans of antiquity who produced myth as arts. ${ }^{49}$ Since their times of imperial city states, art has been an end in itself for the Europeans. 50 When Europeans turned into coloniser en masses their artistic buds, from the start, rejected foreign myth and failed to appreciate any other flavour of cultures that had their own aesthetics, often as village and tribal cultures. Later, science and technology perverted colonisers taste even more. Plato constructed "the political," by the same token delimiting "the philosophic" as such through the exclusion of myth - and of major art forms linked to it - from the pedagogy of the citizen and more generally from the symbolic space of the city. ${ }^{51}$ Ancient Plato can be pitted against modern 'Gandhi,' using Nandy's psychoanalysis of Gandhi.52 Gandhi rejected history for a mythology of the subaltern, the tribal, the rural and the women of India.

Thus Plato's politics discarded myth for history whereas Gandhi's politics discarded history for myth. This constitutes an enchanting discourse. History will decide who between Gandhi and Plato; who of two was decisive as a liberating force in the struggle against colonialism. Gandhi's choice of myth does not render him ineffective. He rejected a chronicled past in his self-styled resistance to colonialism. History, as he saw, was a narration of the elite, both, in the West and in the East. His mythology gave history to the women, the folk, the subaltern and the tribal cultures which constitute the majority of oriental population and therefore the majority of semiotic imaginations, mostly unrecorded in history. Ashis Nandy reminds us that Gandhi, for example,

[n]ever cared for chronologies of past events. ${ }^{53}$ History to him was a contemporary myth which had to be interpreted and reinterpreted in terms of contemporary needs. 54

Gandhi's mythological devices of ahimsa (non-violence) and satyagrah (truthful request) are not only the most original of the devices of international relations for cultural defence invented in the twentieth century, but they prove beyond doubt, the relevance of mythology over history and science. Arguably, they are two components of his mythological materialism. Success of Gandhi and failure of Subhas Chandra Bose, while

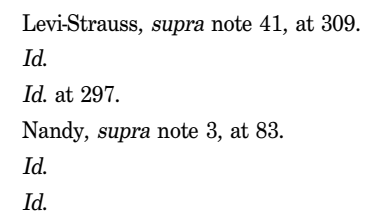


seeking same end i.e. liberation of India, can be attributed to the ability of Gandhi to create a political tool out of India's memories and to what Habermas agrees as "future oriented memories." 55 History is, arguably, always constructed by the authorship of elites whereas mythology always 'exists,' albeit in the imaginations of the non-elites and in texts that are called religious and superstitious. Gandhi demonstrated that those who seek liberation and freedom must learn that "history can sometimes be made to follow from myths." 56 In a way India fashioned, in Gandhi, a discourse of science versus mythology.

It is only now that we have begun to assign rights to the tribal people under international law. However, they are far from getting justice. History has not been able to save them; mythology can. History, unfortunately, reduces people and incidents to data and statistics whereas mythology sees them as lucid and emotional entity capable of establishing dialogues unrecorded in history. History neutralises any emotion that may be associated with the non-dominant actors like the folk, the tribal and the subaltern whereas myth puts flesh and blood into them. Kantian cosmopolitanism added a functional variant to so-called law, made international by consequential rather than accidental ventures, for sympathetic modernisation of colonies. 57 Because something that is beautiful is not always systematic and productive, science used this as an excuse to create an antipathy for Oriental aesthetics and civilisation.

Capitalism relied only on productivity, system, process, market and management. It justified violent revolution, legitimised the eradication of non-modern and nonindustrialised societies by colonial interventions. It was rewarded by raw materials, cheap labour, slave, exotica, new mass of land, and land induced prosperity. This prosperity gave them wealth to purchase political power in a democratic systems back home. This vicious circle was profitable for the coloniser and degrading for the colonised. Meeting of the West and the East, thus, led to a capitalist consensus that the orient was beautifully ugly, logically illogical, systematically unsystematic, articulately subtle, and dysfunctionally functional. 58

Many claim, count Marx among them; that the non-West should accept the debt of the colonisers as harbinger of modernity, knowledge, science, medicine wealth and light. What I fail to understand is if at all colonisation intended charity, why was it so ugly? An ugly charity is no charity. Claims that the non-West did not have enough intellectual force to affect its rise often come from arguments of historical materialism. Why not reject it for mythological materialism? This brings us back to the issue of choices that modernity

\footnotetext{
55 Jürgen Habermas, Moral Development and Ego Identity, in Communication And the Evolution of Society 69 (Thomas McCarthy tRans., 1979).

56 Nandy, supra note 3, at 63.

57 Peter Niesen, Colonialism and Hospitality 3 PoL. \& ETHICs Rev. 90-108 (2007).

58 Singh, supra note 10 , at 14-19.
} 
made. Mythology, I propose, is the sixth past that modernity has overlooked for its own survival. One of the major distinctions between myth and history is that the former is continuous; it encapsulates the past, present and future, whereas the later is fractured. Mythology has the inertia of motion that does not need ignition whereas history has to be woken out of slumber resulting in revolution, often justifying violence as means to modernity's end. And when I say violence, I mean all kinds of violence; violence of act, violence of words, and violence of thought - all of which result in the violence of art. By the early second half of the twentieth century, probably due to the vagaries of two world wars, western scholarship had recognised the truth of myth. Levi-Strauss, thus, commented that:

[s]ame logical processes are put to use in myth as in science, and that man has always been thinking equally well; the improvement lies, not in an alleged progress of man's conscience, but in the discovery of new things to which it may apply its unchangeable abilities. 59

The kind of "logic used by mythological thought is as rigorous as that of modern science, and that the difference lies not in the quality of the intellectual process, but in the nature of the things to which it is applied." 60 Thus the choice of historical materialism over mythological materialism seems suspect. This is understandable. History is a contested narration of progress, myth is not. For modernity to justify true past as evolution, myth must not have any place. Accepting myth would immediately lead to embracing that we have never been modern. Myth proves that men have always been intellectual; all cultures in the world, Indian, Chinese, Egyptian, Mayan and others, have produced similar myth. This rejects any anthropological theory of a superior race which also discards the evolution of races and Whites at the top followed by Browns, Arabs, Yellows and Blacks stranded at different levels of evolution.

\section{Coloniser versus Colonised's Knowledge: Architecture as Art}

Appadurai argues "that hierarchy is one of an anthology of images in and through which anthropologists have frozen the contribution of specific cultures to our understanding of the human condition." 61 "Such metonymic freezing has its roots," he

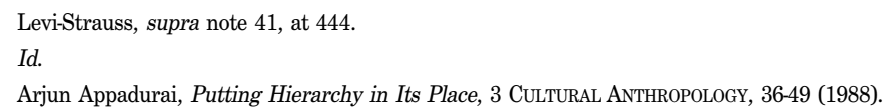


continues, "in a deeper assumption of anthropological thought regarding the boundedness of cultural units and the confinement of the varieties of human consciousness within these boundaries." 62 Very interestingly, tribal existence is one of the dimensions that claim to redefine modernity from an anthropological standpoint conceding that "anthropology, history, archaeology, and other disciplines jostle one another to lay authoritative claims to the pasts of modernity." 63

\begin{abstract}
Although the term native has a respectable antiquity in Western thought and has often been used in positive and self-referential ways, it has gradually become the technical preserve of anthropologists. Although some other words taken from the vocabulary of missionaries, explorers, and colonial administrators have been expunged from anthropological usage, the term native has retained its currency, serving as a respectable substitute for terms like primitive, about which we now feel some embarrassment. 64
\end{abstract}

Western Science has progressed with an imagined animosity as against so-called primitiveness and irrationality of the Orient. Pre-modern reason, rationality, conceptions of beauty and aesthetics of the non-Western civilisations collectively constituted an antithesis to the new Western science. But this science failed to appreciate that every culture produces its own science like each scientific achievement produces new cultural realities. Western science symbolised disciplines like architecture as a discipline worth pursuing. Houses and palaces were soon to become more geometrical with spheres, domes, cylindrical Roman pillars and rectangular windows as against previous symmetries of pre-geometrical sculptures and designs of flora and fauna. Mathematics formed the root of architecture like it was the base of all the sciences as August Comte liked to believe. 65 Architecture fundamentally altered the ratio of labour and raw materials in a rapidly industrialising Europe.

This is the mathematics of colonisation - pure and simple. This new mathematical formulae used natives of the non-West as the catalytic co-efficient of modernity's expansions. Lesser labour and raw materials and more skills in drawing maps were required now. Artists therefore turned into engineers. Thus old art ushered in modern art. Engineers were now the new artists who were ably supported by colonised labourers. This heralded the birth of technology. Myth as a language exposes the vulnerability of poetry to translations and transportations to foreign cultures whereas technology travels well even in its translations. This also is a reason behind technology's acceptance away from its

62 Id.

63 Shami, supra note 4, at 221.

64 A. ApPaURai, Hierarchy in its Place 36 (1988).

65 S.M.Dubey \& Dinesh Sharma (ED.), Sociology: An InTroduction 6 (Susheela Dobhal trans., 1990). 
headquarters and its burgeoning followers among its slaves. Myth in a way has universality at its core, unlike poetry its substance does not lie in the style of narration but in the story it tells. 66 Thus technology transplanted its universality into modern art and its latent cultural violence manifested as fashion. Thus, what we often see among the victims of fashion is the violence of art. Fashion, an offspring of modernity is the cultural violence of modern art. Archaeology, architecture and fashion thus have a common father; technology.

Not many have noted that the art of the non-West, like science, has manifestly been tied to the voyage elsewhere. But enquiries about such artistic location are glued in "complicated ways to the history of European expansion, the vagaries of colonial and postcolonial pragmatics, [and] the shifting tastes of Western men of letters." 67 Though all anthropologists traffic in otherness, some others, Appadurai feels, are more other than others. The culture of anthropology has been driven by the plea of "the small, the simple, the elementary, and the face-to-face." 68 The Anthropology of composite nonWestern societies has, till recently, been a second-class citizen in anthropological discourse. This engages a kind of repeal non-Westernism, whereby "complexity, literacy, historical depth, and structural messiness" 69 function as exclusions in the struggle of places for accent in metropolitan theory. Yet this classification of the responsibility of multifarious time-honoured civilisations in anthropological theory is "too simple and conspiratorial." 70

Idioms as capsules of knowledge, originating in the East, were never swallowed in the West or by the colonisers. Such capsules have remained limited in its appeal to the international community whereas the domestic idioms of the West expressed in Latin, French and German maxims have been made fairly international first through colonisation and then through advocacy, scholarship, politics of knowledge creation and cultural domination. Knowledge is not a singular unit of global wisdom but a category constructed with a fair bit of elitism, discrimination, Eurocentricism and antiOrientalism. The rejection of mythology is its immediate effect.

Bringing the insights of botany, zoology and Darshan (philosophy) together, Jha and Tiwari have made certain scientific observations in ancient Indian philosophy. Elaborately expressed in the pristine Sanskrit maxim, laukik nyaya sutras (idioms of earthly, material, and practical justice), these are specimens of a cordial cohabitation of both the sciences, natural and social, in Indian philosophical mythology.71 These idioms

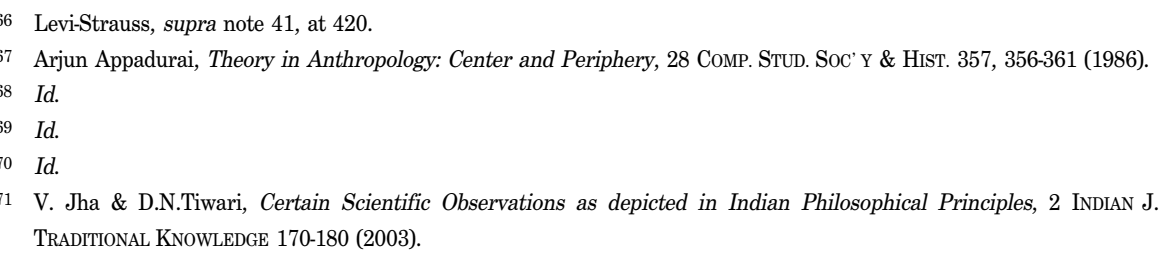


have, brought science closer even to a layman and today, in India, they are a part of the vernacular knowledge system of over fifty languages and one thousand dialects. In a semantic antagonism today, all that is history in the East is mythology to the West and all that is history to the West is a myth to the East. Mythology, in one of my conceptions, is nothing but fossilised history. 72 History was harnessed and funded by the disenchanted industrialised bourgeois for colonial conquests.

\section{International Law as Foucault's Psychology}

The parallel of international law and Foucault's critiques of psychology, for example, is a fascinating discussion. Woven throughout my overall argument, such an approach would strengthen the argument paralleling the madness/unreason that Foucault traced in the European asylum, and the unreason colonial discourses have ascribed to indigenous knowledge systems. This narrative seeks to create a clearer path leading the reader through the complexity of the greater argument because international law is as psychological, sociological, and political as it is legal. Sympathising with the victims of modernity and science, who fall outside the periphery of the civilised world, I shall, thus, "offset myth against science" and history of international law.73

Table 3 : Madmen versus Colonised

\begin{tabular}{|l|l|}
\hline Mad people in Europe & Colonised Natives \\
\hline Madness/poverty (Calvinism) & Cultural and material destitution \\
\hline Caged in "houses of Correction" & Confined in their own native land \\
\hline Provided unpaid/free labour & Free labour \\
\hline Labour-hood as prescribed medical treatment & $\begin{array}{l}\text { Civilizing though punishment, rules and } \\
\text { institutions }\end{array}$ \\
\hline Used as a tool to come out of financial crisis & Producing raw materials and as market both \\
\hline Confinement hid away "unreason" & Laborhood produced market \\
\hline $\begin{array}{l}\text { Classicism deemed madness as hidden } \\
\text { animality as return to kindness of nature }\end{array}$ & Natives a prototype of Madmen \\
\hline Question of philosophy/psychology & Subject of anthropology \\
\hline
\end{tabular}

Source: Edited by the author (based on the text by Nandy, supra note 3, at 14-15)

72 For a powerful discourse on the science of mythology, see C. G. Jung \& C. KerÉNYI, Essays on a ScIENCE OF Mythology: The Myth of the Divine ChILD AND the Mysteries of Eleusis (2001).

73 Nandy, supra note 3 , at viii. 
Classic International law is an expression of Western attitude similar to the one harboured for madness of Foucault fame. Non-Western man is the classic international law's madman. Views about madness led the West to confine madmen between four walls of lunatic asylums. International law's madmen were by the same logic supposed to be confined between the walls of corrupt science and plastic modernity. The Oriental madmen of international law had to be confined, policed, and cured. Madness was unscientific

... which in the eyes of history must appear as ... the reduction of the classical experience of unreason to a strictly moral perception of madness, which would secretly serve as a nucleus for all the concepts that the nineteenth century would subsequently vindicate as scientific, positive and experimental. ${ }^{74}$

The madman was savage and industries needed labourers. The classic period in Europe hailed a labourer as someone whose "world suffused with wisdom ... which cures madness." 75 Madness, thus, had to be cured with the punishment of labourhood. The conception of punishment draws its power from the contractual exchange relation between creditor and debtor, which is an idea as old as legal subjects. The fundamental forms of buying, selling, barter, trade, and traffic could be ensured through labourhood. Labourhood, either in field or in industry looped labourers in the cycle of work i.e. to produce, buy and consume. Thus all those outside the vicious circle of industrialisation and modernity had the risk of being called mad and therefore, policed into confinement. They had, thus, the responsibility of proving otherwise by their labourhood. The ideas of contractual, obligation and repudiation of contract leading to punishment were soon to follow.

The original instinctual artists who formed man exchanged the creditor's psychological pleasure in inflicting physical pain for the debtor's infraction of the communal contract. Later, theologians and moralists spiritualized punishment; they replaced physical with psychic pain. The history of culture is the spiritualization of cruelty. 76

Foucault's "Archaeology of knowledge" wherein for him, archaeology, a discipline about silent monuments and inert remains of the past, hides the narratives of modernity. Thus if archaeology is a seed of modernity then megacity is the tree that

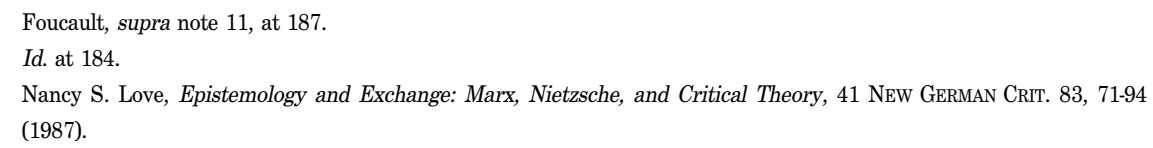


germinates out of it. Modernity here becomes a project of producing a megacity of super structures. But Foucault did change between 'Archaeology' and "Discipline and Punish" in his conception of history. With the growth of megacities in modern Europe the rural came to be condemned as backward and the poor as immoral, deprived of the fruits of labour and doomed to live in slums. In "Madness and Civilisation," Foucault points to the "mode of perception which we must investigate in order to discover the form of sensibility to madness." 77

The sensibilities about madness "organises into a complex unity a new sensibility to poverty and to the duties of assistance, new forms of reaction to the economic problems of unemployment and idleness, a new ethic of work and also the dream of a city where moral obligation was joined to civil law, within the authoritarian forms of constraint." 78 Foucault's next observation is rather direct - "have you not yet discovered the secret of forcing all the rich to make all the poor work? Are you still ignorant of the first principles of police?" 79 Hidden in the attitude towards the madmen and the poor and its professed cure in confinement lies the corrupt sympathy of the rich West for the poor of the non-West, manifested in the international overtures of transnational law.

Driving both the mad and the poor into confinement while heralding the birth of policing, the seventeenth century Europe endeavoured to solve the problems of unemployment! De novo corrupt scientific prescriptions for curing both, madness and poverty, was confinement! We see the reflection of this antipathy to poverty in England in its "Poor Law" as well.80 A dream city of the rich bourgeois was designed by driving the poor out of cities. 81 Such pathologies of seventeenth century Europe regards slums closer to village life even though there are marked differences between both. In the culture of Vedic India, village was as modern a thought as the megacity of science, for example. This is another way of putting what Levi-Strauss means when he says both myth and science are intellectual work of equal merit. 82

Western narratives of linear modernity, exposed by Foucault, are guilty of ignoring non-Western ethos for which modernity is a circular path of both mega and minimal structures. Confinement constituted a sole possible answer that seventeenth century Europe offered to "an economic crisis that affected the entire Western world: reduction of wages, unemployment [and] scarcity of coin(s)!" 83 This attitude of confinement translated

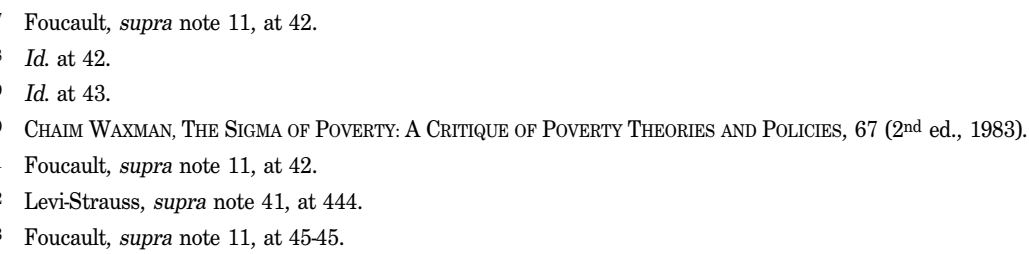


into the spirit of colonisation under the pressure of market, modernity and science. Thus, Alexander's greatness, Nazi's passion for blood-curdling art and Foucault's vision of madness, all align, though psychologically, with the regression of art and science. As if this was not enough the colonisation assumed a role of a teacher in India to subject its people by alien sets of norms, rules and laws. Indian Myth was overrun by the history of Europe that shamelessly justified its aggression as benevolence. One should not forget that Alexander did try to colonise India by leaving his satraps, Seleucus is the most famous of all, to manage his conquered territories on his behalf. Only for a powerful uprising of Chandragupta and Kautilya this bid of colonisation was averted.

\section{Critical Debate between the Orientalist and the Anglicists: The Utilitarian Universalists}

Edward Said's Orientalism has done enough service to the cause of the non-West.84 His brilliant work exposed the formation of the 'political' knowledge and the making of the East. The construction of the Occident, he figured out, was piled upon the base of Orient. 85 It is precisely because of this image making that Max Müller advised his student not to visit India despite his translative works on Indology. India of ancient times, he believed, was dead, and what was left during the British rule was not the true India. 86 Yet a discussion about this, however repetitive it might appear, is a necessity.

The major difference between those living in history and those living outside it, especially in societies where myths are the predominant mode of organizing experiences of the past, is ... the principle of principled forgetfulness. All myths are morality tales. Mythologization is also moralization; it involves a refusal to separate the remembered past from its ethical meaning in the present. For this refusal, it is often important not to remember the past, objectively, clearly, or in its entirety. Mythic societies sense the power of myths and the nature of human frailties; they are more fearful than the modern ones -forgive the anthropomorphism - of the perils of mythic use of amoral certitudes about the past. 87

The hedonist calculus of Jeremy Bentham at once recognised the historical potential of his idea about the ahistorical Indians. The Orientalists supporting the ahistoricity of

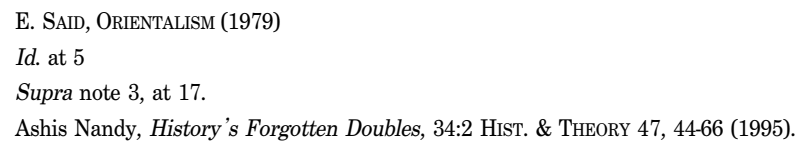


India wilted and gave up under the pressure of Anglicists' advocacy. Thus, utilitarianism rejected the Orientalist respect for indigenous knowledge. The 1857 Mutiny stamped the British project of reforming India through utilitarianism. Bentham, the key architect of its administrative colonisation, planned the administrative and judicial process of civilising India. The East India Company, most powerful coloniser and capitalist of those times, employed his services. Eric Stokes shows the striking influence of Bentham in Indian affairs, particularly in the field of legal reform. The new agenda of civilisation through legalisation began by wiping out all of Mugal and preMugal ahistorical administrative system for a historically accented British mode of governance. Utilitarianism steered in an era of paper-planning and routine law codes: "the sword was to be exchanged for the pen and the soldier diplomat to give way before the administrator-judge." 88 The Indian Legislative Council inspired by Bentham led to a series of Acts in the mid-19th century designed to facilitate the efficient administration of justice. The Civil Procedure Act 1859 "promised to secure so far as judicial institutions can secure that blessing, as good and accessible an administration of civil justice as the lights of the age are capable of conferring on it." 89 The Penal Code 1860, and the Code of Criminal Procedure 1861, brought changes to criminal jurisdiction. These are some of the facts that amply demonstrate the British effort of introducing modernity into the ahistorical India. Similar to the discussion about Foucault and international law;

Every society has a mythology surrounding the origins of rules of conduct and systems of law, revealing that law is not based on experimental data. Such myths most often begin with a postulated relationship to a sacred presence or personage in the universe that might be viewed as "contractual." Cultural groups may or may not have sacred places and objects, but in all of them the foundations of rules of conduct and proper relationships to persons, animals and things cultural or natural, reside in the contract with the sacred power. The contract includes agreement about good and evil (crime and punishment), group membership (allowed and disallowed, with exclusionary provisions), marriage rules, sexual taboos, sexual access and denial, punitive measures meted out through illness, death, or the many forms of loss, as well as some advice for conflict resolution. 90

A proficient legal system was also central to the idea of administrative superiority asserted ruthlessly. Both, an efficient law and a strong government were pivotal for this much sought-after growth-spurt in maximum happiness: law should provide a rational

\footnotetext{
8 ERIC Stokes, The English Utilitarians AND India 13 (1989).

89 Id. at 259

90 Lola Romanucci-Ross \& Laurence Tancredi, When Law and Medicine Meet: A Cultural View 21 (2004).
} 
and convenient framework in which the new state of things may prosper. ${ }^{91}$ It largely carried out its agenda so that the rule of law might complete its civilising mission. ${ }^{92}$ The principle of pleasure is thus defined in the negative, by what it excludes. 93 The way in which the success of an administrative, executive or judicial system is measured is according to whether or not it mitigates against evil hindrances, rather than in terms of a happiness-effect. 94 This is certainly true of the Benthamite reforms implemented in British India. 95 To continue with the earlier discussion, the utilitarianism was modernity in disguise - its colonial architecture planned in accordance with the erstwhile biggest capitalist, the East India Company. This reform was marked by a new cultural relativism which saw Indian culture as 'infantile' and 'immoral' against the promoted British culture through British public school products; the westernised Indians were declared austere, courageous, self-controlled adult men as against the illiterate, superstitious, and infantile natives. 96 It is this political and cultural adulthood assigned to the educated Indians that Gandhi rejected and instead chose myth over manufactured history.

\section{Indian Subaltern Studies}

In his book, "Discipline and Punish," even Foucault reminds us of Jeremy Bentham, the utilitarian. ${ }^{97}$ In the Panopticon, Bentham says in the preface of his work:

Morals reformed - health preserved - industry invigorated - instruction diffused public burdens lightened - Economy seated, as it were, upon a rock - the Gordian knot of the poor-laws not cut, but untied - all by a simple idea in architecture!98 [Foucault thus maintains] Bentham envisioned the same basic concept of factories, schools, barracks, hospitals, madhouses ${ }^{99}$... [the prison succeeded disciplining a man into] a docile worker who does as ordered without question - and automation, the perfect fodder for Capitalist factory. 100

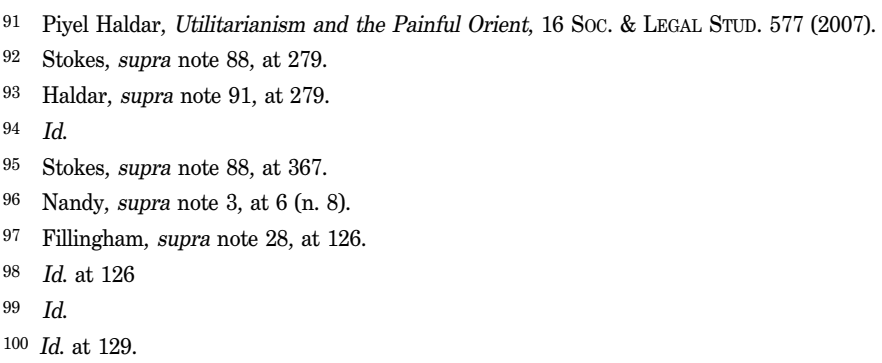


Now if Bentham saw his own people as those needing correction - as discussed above does it surprise the readers that his policies of colonial management of the 'Other' were so harsh. This preface to his work is a crystal ball of his hedonistic calculus. The elite historiography that was pursued in India after independence only continued the tradition of Bentham without any epistemological break. This historiography wrote away subaltern reality of India as a myth. An effort in restoring the falsity of Indian elite has another name called the "subaltern studies." Gayatri Chakravorty Spivak admits that "[S]outh Asia model postcolonialists have not come to grips with the fact that India, with its ninety million Aboriginals, is a precapitalist, precolonial, non-European settler colony, where the postcolonial Hindu-majority Indian is, roughly speaking, the first settler - and even such a formulation is mired in Aryanist nonsense." 101 No wonder, the work of scholars in the 1960s raised controversial questions regarding the nature and results of the colonial rule in India. Did the imperialist British deserve credit, they asked, after all for making India a developing, modern, and united country? Dipesh Chakrabarty sums up the spirit of enquiry among rebelling historians who discarded the Cambridge school of historiography, better than anyone else;

Official documents of the British government of India - and traditions of imperial history writing - always portrayed colonial rule as being beneficial to India and her people. They applauded the British for bringing to the subcontinent political unity, modern educational institutions, modern industries, modern nationalism, a rule of law, and so forth. Indian historians in the 1960s - many of whom had English degrees and most of whom belonged to a generation that grew up in the final years of British rule - challenged that view. They argued instead that colonialism had had deleterious effects on economic and cultural developments. Modernity and the nationalist desire for political unity, they claimed, were not so much British gifts to India as fruits of struggles undertaken by the Indians themselves. 102

Ranajit Guha, the pioneer of the subaltern studies, insisted that instead of being a survivor in a modernizing colonial world, the peasant was a real contemporary of colonialism and a fundamental part of the modernity that colonial rule gave rise to, in India. 103 Comparatively, the peasants were more violent than the elites. However, history, unlike mythology, is authored and the peasants cannot be expected to maintain written records like the intellectuals. But the absence of peasant autobiographies and the

101 G.C Spivak, Foreword: Upon Reading the Companion to Postcolonial Studies, in A CoMPanIon to Postcolonial STUDIES, xvii, xv - xxii (H. SCHWARZ \& S. RAY EDS., 2000).

102 Dipesh Chakrabarty, Subaltern Studies and Postcolonial Historiography, 1 NEPANTLA: Views from South 11, 9-32 (2000).

103 Id. at 17. 
recognition of this absence forms the semiotic base of the subaltern studies. A notion of resistance against the elite history was vital to subaltern motivation. The Peasant uprisings in colonial India, Ranajit Guha argued, reflected this separate and autonomous grammar of mobilization "in its most comprehensive form." 104 Even in the cases of resistance and protests by urban workers, the "figure of mobilization" was one that was "derived directly from peasant insurgency." 105

The Subaltern Studies was in part a product of a metropolitan Marxist traditions of a history from below. But the nature of political modernity in colonial India made this project of history writing nothing short of an engaged critique of the academic discipline of history itself. The semiotic theories take signs or sign systems as their object of study. Subaltern studies was essentially a project of looking for indigenous signs of resistance to modernity i.e. peasant struggles in India, against the elitist historiography. The subaltern reality of India filed away by the officially documented history of British historians can be studied as history of communication of the signs that the regular peasant uprisings against colonial rule had produced, rediscovered later. Afterwards, the subalterners have examined areas belonging also to the natural sciences. Now its time for us to turn to pragmatics: the branch of semiotics that deals with all the psychological and sociological phenomena which materialise in the functioning of signs. This paper is a little step in that direction.

\section{Signification of International Law}

Myth can also be seen as language that needs decoding. 106 Thus, what is needed then is an application of the theory of signification. The theory of signification if applied to international law has an insightful potential. However, this paper does not mandate a fulllength deliberation on the grammar and dialectic of international law while signifying it. Yet, there are many mainstream international law scholars, like Martti Koskenniemi, who have expressed concerns on the grammar of international law, particularly for its universality. 107 B.S. Chimni however, feels that such a critique of international law from the West, identified as new approaches to international law ("NAIL"), does not offer solutions unlike the third world approaches to international law ("TWAIL").108

\footnotetext{
104 Id. at 16.

105 Id. at 16.

106 Levi-Strauss, supra note 41, at 430.

107 Martti Koskenniemi, From Apology to Utopia: The Structure of International Legal Argument (2005).

108 B.S. Chimni, Towards a Radical Third World Approach to International Law, 5 ICCLP RevIEw 1, 4-26 (2002).
} 
Nonetheless, this debate takes us to the issue of myth in international law. Koskenniemi thinks that finding equitable solutions or knowing who the aggressor is or when to launch a humanitarian operation would not be impossible or even necessarily difficult.109 But little about such a decision-making can plausibly be seen in terms of employing a legal vocabulary of rules and principles, precedents or institutions. 110 Instead, the relevant considerations always seem to require technical expertise, calculations of the data produced in the context in order to figure out the best outcome.111 Thus the problem of science in Koskenniemi's characterisation is actually a problem of technicality.

The power of myth must be reawakened, in opposition to the inconsistency of the abstract universals (of science, of democracy, of philosophy) and in the face of the collapse (fully realized in the war of 1914-18) of the two beliefs of the modern age: Christianity, and the belief in humanity ...112

Mired in the interpolations and the polemic of development, international law is essentially an exercise in semiotics. The aim of universalising international law contain the hidden agenda of capitalist avarice that has a bearing on the grammar and dialectic of international law's language. The language of international law and its potential room for dialectic is indeed of prime importance for the subject that is sought to modernise and civilise. For example, the grammar and dialectic of this law justifies the project of exploitation of the tribal peoples around the world, all in the name of development.

\section{Conclusion}

While, contextualising semiotics, development and modernity in international law we automatically come to "constitutionalist discourses." Hidden in the symbolism produced beyond the text of a constitution, similar in accent to the history texts authored by the elites, are signals of resistance offered by the text-less, illiterate, and socalled backward, non-Western sentiments. The semiotics of law must capture it. Acclaimed human rights' scholar Upendra Baxi writes that:

\footnotetext{
109 Martti Koskenniemi, The Fate of Public International Law: Between Technique and Politics, 70 Mod. L. REv. 10, 1-30 (2007).

110 Id.

111 Id.

112 Lacoue-Labarthe \& Nancy, supra note 13, at 307.
} 
The history of evolution of modern constitutionalism is a narrative of growth of asymmetries in domination and resistance. Principles of constitutionalism were perfected in Europe at the very historic moment when colonialism flourished. In retrospect, the narrative of constitutional development in decolonized societies provides a massive indictment of accomplishments of liberal thought.113

An ideal type investigation methodology in social sciences while serving the cause of a composite international law is much more than a simple lip-service of its relationship with semiotics. Consequently, the task of the semiotic study of history is to observe numerous individual cases abstracting typical characteristics. Mine is such an exercise. An ideal investigation of various kinds of pasts to reveal the status of the present never really exists in reality; it is instead a pure theoretical configuration. Semiotics helps to an extent in locating and interpreting the signals and signs hidden in mythological narrations which unlike history are not authored. Since true myth is un-authored, the chances of finding truth in its symbolism are very high. The Frankfurt School has long criticised the positivism of scientific studies that ignore psychological aspect of value creation. As a consequence, we can see how myth was rejected for history that tried to subdue certain signals of equality and apathy for similar activities globally. It will now become clearer why Plato rejected myth in his politics and as soon as the Second World War was over, the Frankfurt scholars went back on their agenda of anti-fascism.

Today, not many people would believe in the plurality of science. The mainstream view on science would not believe that "there can be politics or culture in the content of science."114 On the sociological level one solution could be to understand the diverse moorings of diverse civilisations. For example, any attempt to align the tribes with today's selfish modernity is an act of aggression and expression of modernity's superior science over those who either fail to understand it or who do not wish to engage with it. The birth of disciplines has obscured "cultural and intellectual values from the point of view of defeated systems of knowledge, and with the psychological costs of confronting an imperial system of knowledge outside the western world." 115 International law has been a language of colonisation and therefore modernisation. On a theoretical level, therefore, we can debate whether international law is a science, natural or social, or simply an alleged servant of the empire. International lawyers, like other social scientists, are the makers and managers of meaning in a much deeper way than most lawyers actually realise. They not only manage meaning of law but are also managed by it. Thus, the question of authority and source of knowledge is very important to

113 Upendra Baxi, Postcolonial Legality, in Schwarz \& Ray ed., supra note 101.

114 Ashis Nandy, Alternative Sciences: CReativity and Authenticity in Two Indian ScIENTISTS, viii (2nd ed., 2001).

115 Id. at ix. 
understand international law on a semiotic plane. The sources of knowledge, not only legal, constitute longstanding discussion. The distinction between the East and the West has been its symbolic attachment with knowledge's semiotics. History has been the origin of western knowledge whereas myth has been the mother of Eastern knowledge.

Lingustic studies of myth have shown that structures of myth are as rigorous as that of science. Thus what obscures myth against science is the paucity of semiotic vision in law. Unfortunately, not many scholars in international law have been able to appreciate semiotics as an important vehicle for a full blown alternative vision of international law. Semiotics of international law should not be confused with myth-science animosity; rather as a possible bridge between them. Semiotics is the art of revealing symbolism hidden in the epistemology of myth. Thus, civilisations with its myth can potentially provide solutions not imagined before. The search for alternative vision of international law is such an exercise. The structural studies of myth carried in anthropology have not been adequately followed in international law. Foucault and other post-modernists have usefully used semiotics to employ myth to reality. Appadurai's discourse on the past and its boundaries is only a modicum of this alternative vision. An ounce of Foucault's and another from Nandy's mixed into Appadurai's could turn into a possible panacea of semiotic vision on modernity, myth and past. A commissioned study for intellectual exploitation of this medicine can definitely cure some of the open wounds inflicted by intellectual harangue against the non-Western knowledge systems. My most serious concern is that the globalisation of prosperity is creating new elites and de-eliting some of the old members. The scene remains unchanged as new patterns of poverty, injustice and exploitation are only changing geography and race. International law must capture this changing semiotics. 
